\title{
Non-Linear Error Functions Approach to Kinetic Study of Arsenic Removal from Soils using Proteus mirabili and Bacillus subtilis
}

\author{
Atikpo, E. ${ }^{1, *}$, Agori, J.E. ${ }^{1}$, Iwema, E.R. ${ }^{1}$, Michael, A $^{2}$ and Umukoro, L.O. ${ }^{1}$ \\ ${ }^{1}$ Department of Civil Engineering, Faculty of Engineering, Delta State University, Abraka, Delta State, Nigeria \\ ${ }^{2}$ Department of Animal and Environmental Biology, Faculty of Sciences, University of Benin, Edo State, \\ Nigeria \\ Corresponding Author: *eguasbridge@gmail.com
}

\begin{abstract}
Kinetics of arsenic (As) removal by Proteus mirabilis and Bacillus subtilis were studied using the non-linear error functions approach. The two microorganisms (from soils samples obtained from a contaminated site in Amaonye-Ishiagu in Ebonyi State of Nigeria) were cultured and employed to deplete the metal ion from the contaminated soils. The experimental data were studied with four kinetic models namely pseudo first order, pseudo second order, simple Elovich, and intraparticle diffusion models using some non-linear error functions of root mean square error (RMSE), standard error of experiment (SEE), average relative error (ARE) and normalized standard deviation (NSD). Data from removal by both organisms were best described with pseudo first order model indicated by the ARE of minimum value of -1.8728 for Proteus mirabilis, and -2.1208 for Bacillus subtilis. These showed that the removal mechanism was reaction controlled as chemisorption was the rate limiting step.
\end{abstract}

Keywords: Arsenic, Bioremediation, Error functions, Kinetic models

\subsection{Introduction}

The commonest heavy metals seen at contaminated sites are lead $(\mathrm{Pb})$, chromium $(\mathrm{Cr})$, arsenic (As), zinc $(\mathrm{Zn})$, cadmium $(\mathrm{Cd})$, copper $(\mathrm{Cu})$, and mercury $(\mathrm{Hg})$ in their order of abundance (USEPA, 1996). These metals are significant since they have the capabilities to decrease crop production by reason of the risk of biomagnification and bioaccumulation in food chain; and risk of contamination to surface and groundwater (Wuana and Okieimen, 2011).

Heavy metals laden sediment causes many health and ecological related problems. These contaminants have become one of the vital ecological problems of health consequence (Aktan et al., 2013). Exposure to arsenic in early life is connected with increased risk of adverse health effects that can remain till adulthood (Smith et al., 2006; Steinmaus et al., 2014; Bailey et al., 2016). This was the case of the nearly 50 -fold raised standardized mortality ratio of people with bronchiectasis in a number of young adults in Chile who got exposed to high levels of As in utero and during childhood compared with mortality rates of the rest population of Chilean (Smith et al., 2006).

Close to every organ in the body of human being is readily accessible to arsenic exposure, with many health consequences like lung disease, diabetes, skin lesions and cancer (Naujokas et al., 2013). Patients of chronic arsenic exposure, show inflammation of the respiratory membrane; cardiomyopathy, skin disease, destruction of red-blood corpuscle; leucopenia; jaundice; renal damage; ataxia; irrational speech, paralysis; poor memory and degeneration of inner ear (Athar and Vohora, 2006).

Bioremediation is regarded as one of the safer, cost effective and ecological suitable technology for treating sites which are polluted with diverse pollutants. Thus, it has become the most effectual management means to control environmental pollution and restore polluted soils to their natural status 
(Kulshreshtha et al., 2014). It involves the use of biological agents like bacteria, algae, fungi and higher plants to eliminate toxic bodies from the environment (Kulshreshtha et al., 2014). Bioremediation is an innovative technology for heavy metals removal from polluted lands by microorganisms through different mechanisms such as biosorption, biotransformation, bioaccumulation and biomineralization (Girma, 2015).

This work was carried out to study biosorption and the kinetics of removal of arsenic ion by Proteus mirabilis and Bacillus subtilis. The kinetics of removal were analyzed using pseudo first order; pseudo second order (Ho et al., 2000); simple Elovich (Chien and Clayton, 1980); and intraparticles diffusion models by concentrating on the non-linear error functions to compensate for the altered error structure and the violated normality assumption during linearization of the mathematical kinetic models. This is arising from the difficulty in establishing the accuracy of kinetic models.

In most studies, linear regression has been used for this purpose because of its simplicity. The linear least-square approach has also been used with linearized kinetic equation with a reliance on the coefficient of determination close to or equal to one (1) in establishing accuracy of fitted models (Ho, 2006). This approach was characterized with alteration of error structures and normality assumption which has led to a later development of the use of non-linear optimization modeling with error functions intervention to restore normalcy to the altered model structure (Kumar and Porkodi, 2007; Passos et al., 2008).

Therefore, selecting the best fitted kinetic model for this work necessitated the use of some non-linear error functions such as root mean square error (RMSE), standard error of experiment (SEE), average relative error (ARE) and normalized standard deviation (NSD).

\subsection{Materials and Methods}

\subsection{Reagents and materials}

The materials and reagents used for this research work are presented in Table 1.

Table 1: Materials and reagents for the study

\begin{tabular}{|c|c|}
\hline Materials & Reagents \\
\hline $\begin{array}{l}\text { 1. Magnetic stirrer, 2. Hot plate, 3. Whatman filter paper, } 4 . \\
\text { Autoclave, 5. Refrigerator, 6. MacCartney bottles, } 7 . \\
\text { Incubator, 8. Wire loops, 9. Measuring cylinder, 10. Atomic } \\
\text { absorption spectrophotometer, 11. Cotton wool, } 12 . \\
\text { Inoculating needles, 13. Petri dishes, 14. Microscope, } 15 . \\
\text { Conical flasks, 16. Beakers, 17. Pipettes, 18. Soil samples }\end{array}$ & $\begin{array}{l}\text { 1. MacConkry agar, 2. Safranin, 3. Kovac's reagent, } 4 . \\
\text { Sodium hydroxide, 5. Nutrient agar, 6. Hydrochloric acid, } 7 . \\
\text { Oxidase reagent, 8. Triple sugar iron agar, 9. Sulphuric acid, } \\
\text { 10. Methylene blue, 11. Peptone water, 12. Ethanol, } 13 . \\
\text { Hydrogen peroxide, 14. Simon citrate ager, 15. Crystal } \\
\text { violent, 16. Perchloric acid, 17. Potato dextrose agar, } 18 . \\
\text { Nitric acid, 19. Lugo's iodine }\end{array}$ \\
\hline
\end{tabular}

\subsection{Preparation of nutrients}

The solutions of potato dextrose agar, triple sugar iron agar, nutrient agar, Simon Citrate agar, MacConkey agar and peptone water powder were prepared in accordance with the instruction given by the manufacturers and by following the methods of Cheesebrough (2000). Thirty-nine (39), sixtyfive (65), twenty-eight (28), twenty-four (24), fifty-two (52), and fifteen (15) grams of their respective powered were measured into one litre each of distilled water. The mixtures were left for 10 minutes and swirled to allow for dissolution before autoclaving for 15 minutes at temperature of $121^{\circ} \mathrm{C}$ and pressure of $1.5 \mathrm{psi}$; and then allowed to cool to $45^{\circ} \mathrm{C}$ before usage.

\subsection{Distinguishing the organisms}

Bacteriological analysis was conducted in the laboratory on soils sampled from a village forest at Amaonye -Ishiagu located in Ebonyi State of Nigeria. The soil was diluted serially and $0.1 \mathrm{ml}$ each was obtained from dilutions $\left(10^{-1}, 10^{-3}\right.$ and $\left.10^{-5}\right)$ and dispensed into sterile Petri-dishes containing nutrient agar and MacConkey agar distinctly using the pure plate method (Cowan, 1993 and Baron et al., 1994). 
The distinct plates of inoculums were incubated at temperature $37^{\circ} \mathrm{C}$ for 24 hours (Cheesebrough, 2000), and the yielded Colonies were enumerated, recorded, sub cultured and characterized with the techniques of (Cheesebrough, 2000; Cowan and Steel, 1990; Holt, 1994).

\subsection{Factors screening}

Certain factors at their optimal values give vent to optimal bioremediation processes. Initial experimental investigation of these factors is a requirement for selecting their optimal values. These critical factors: $\mathrm{pH}$, temperature $\left({ }^{\circ} \mathrm{C}\right)$, organisms' weights $(\mathrm{g})$, nutrient dosage $(\mathrm{ml})$ and stirring frequency [per week (pw)] were screened in batches and the experiment conducted in triplicate (Lima et al., 2007; Atikpo and Micheal, 2018).

Nutrient dosage of 1, 2, 3, 4, 5, 6, 7, 8, 9 and $10 \mathrm{ml}$ were introduced separately into thirty (30) beakers $(50 \mathrm{ml})$ containing three grams $(3 \mathrm{~g})$ of soil samples each. The soils in each beaker were inoculated with 24 days old Proteus mirabilis and Bacillus subtilis respectively; and the soils residual arsenic ion content was evaluated on the $14^{\text {th }}$ day with Atomic Absorption Spectrophotometer (AAS) (GBC SensAA, Model no. A6358) after centrifuge action to eliminate the organisms from soils.

The procedure was repeated for 1, 2, 3, 4, 5, 6, 7, $8 \mathrm{~g}$ of organisms' masses; 15, 20, 25, 30, 35, 40, 45 and $50^{\circ} \mathrm{C}$ of temperature; $3,4,5,6,7,8,9$ and 10 of $\mathrm{pH}$; and $0,1,2,3,4,5$ and 6 per week (pw); and their respective optimal values were determined.

\subsection{Arsenic removal study}

Three grams $(3 \mathrm{~g})$ of soil samples in each beaker $(50 \mathrm{ml})$ were inoculated with each selected bacterium. This was done for all the thirty beakers needed for triplicate evaluation (Lima et al., 2007; Atikpo, 2016) of the residual metal ion. The samples were conditioned with the factors' optimum values of $1 \mathrm{~g}, 8 \mathrm{ml}, 30^{\circ} \mathrm{C}, 7$ and $6 \mathrm{pw}$ for Proteus mirabilis; and $5 \mathrm{~g}, 8 \mathrm{ml}, 30^{\circ} \mathrm{C}, 8$ and $6 \mathrm{pw}$ for Bacillus subtilis. The optimum value without a unit is the $\mathrm{pH}$ of the process.

Residual metal ion in soils was determined on the $7^{\text {th }}, 14^{\text {th }}, 21^{\text {st }}, 28^{\text {th }}$ and $35^{\text {th }}$ day using AAS (GBC SensAA, Model no. A6358), after eliminating the organisms from the samples using a centrifuge. The ion removed with time in $(\mathrm{mg} / \mathrm{kg})$, ion removed at equilibrium in $(\mathrm{mg} / \mathrm{kg})$ and the efficiency of removal in (\%) were evaluated using Equations (1) and (2) (Badmus et al., 2007; Chen and Wang, 2007).

$\mathrm{q}_{\mathrm{t}}=\frac{\left(C_{o}-C_{t}\right)}{m} \cdot V$

$\mathrm{q}_{\mathrm{e}}=\frac{\left(C_{o}-C_{e}\right)}{m} \cdot V$

$\varepsilon=\frac{\left(C_{o}-C_{f}\right)}{C_{o}} \cdot 100$

$C_{0}, C_{t}, C_{e}, C_{f}, q_{t}, q_{e}, V$ and $m$ are the initial metal ion $(\mathrm{mg} / \mathrm{kg})$; residual metal ion with time in $\mathrm{mg} / \mathrm{kg}$, residual metal ion at equilibrium in $\mathrm{mg} / \mathrm{kg}$, final metal ion $(\mathrm{mg} / \mathrm{kg})$, volume $\left(\mathrm{m}^{3}\right)$ of soil used and the mass $(\mathrm{g})$ of organisms used respectively.

The experimental data were analyzed with some error functions to determine the fit of pseudo-first order, pseudo-second order, simple Elovich and intraparticle diffusion models in Equations (4), (5), (6), (7) respectively (Ho et al., 2000; Chien and Clayton, 1980; Mckay and Poots, 1980) for the study of the kinetics of the metal ion removal from the soils.

$$
\begin{aligned}
& \frac{d q_{t}}{d t}=k\left(q_{e}-q_{t}\right) \\
& \frac{d q_{t}}{d t}=k_{1}\left(q_{e}-q_{t}\right)^{2}
\end{aligned}
$$




$$
\begin{aligned}
& \frac{d q_{t}}{d t}=\alpha \exp \left(-\beta q_{t}\right) \\
& q_{t}=K_{2} t^{\frac{1}{2}}+X
\end{aligned}
$$

Where $q_{t}$ is removal capacity with time $\mathrm{t}$ in $\mathrm{mg} \cdot \mathrm{kg}^{-1} ; k$ is rate constant of pseudo first order model $\left(\mathrm{d}^{-1}\right)$; $q_{e}$ is removal capacity at equilibrium in mg. $\mathrm{kg}^{-1} ; k_{l}$ is rate constant of pseudo second order model $(\mathrm{kg}$. $\left.\mathrm{mg}^{-1} \mathrm{~d}^{-1}\right) ; \alpha$ is the initial removal rate in mg.kg ${ }^{-1} ; \beta$ is desorption rate constant in mg.kg $\mathrm{kd}^{-1}$; and $K_{2}$ is the rate constant for intra-particle diffusion model.

The error functions computation was carried-out with the solver add-in Microsoft Excel. The relationship of experimental data and time was laid with a polynomial function; and the objective function was minimized with solver at a maximum iteration of 100 seconds and a precision of 0.000001 .

\subsection{Results and Discussion}

Microbial recognition analysis generated the required bacteria from the colony of $2.2 \times 10^{7} \mathrm{cfu} / \mathrm{ml}$. The bacteria were identified with biochemical tests results of positive oxidase, negative indole, negative citrate, positive catalase, positive glucose, negative $\mathrm{H}_{2} \mathrm{~S}$, positive lactose, positive motility and gram positive rods (GPR) in gram stain for Bacillus subtilis; and positive motility, positive catalase, negative indole, negative citrate, positive glucose, negative oxidase, positive lactose, positive $\mathrm{H}_{2} \mathrm{~S}$ and gram negative rods (GNR) in gram stain for Proteus mirabilis.

Proteus mirabilis was found to perform effectively and efficiently at optimum values of $1 \mathrm{~g}$ of organism's weight, nutrient dosage of $8 \mathrm{ml}$, temperature of $30^{\circ} \mathrm{C}, \mathrm{pH}$ of 7 , and $6 \mathrm{pw}$ of stirring frequency; while the optimum values of factor for performance by bacillus subtilis were found to be $5 \mathrm{~g}$ of organism's weight, $8 \mathrm{ml}$ of nutrient dosage, temperature of $30^{\circ} \mathrm{C}, \mathrm{pH}$ of 8 , and $6 \mathrm{pw}$ of stirring frequency.

The specific models for describing the removal of the metal by the organisms were carefully studied by fitting the linear forms of the models and engaging the minimized error functions in scrutinizing the kinetic models. Adopting this approach to the study, the metal removal by Proteus mirabilis was evidently influenced by chemisorption. This was indicated by SEE, NSD, RMSE and the ARE.

Fundamentally, chemisorption governed removal mechanism usually have either a fit of pseudo first order model, pseudo second order model, or the simple Elovich model as the best fit model. However, in this study of As removal by Proteus mirabilis, the simple Elovich model was not among the highlighted, performing models indicated by the error functions. The SEE indicated pseudo second order model, the NSD indicated pseudo second order model, the RMSE indicated pseudo second order model, while the ARE indicated pseudo first order model.

The rate limiting step of this removal is the ultimate requirement of the error function analysis because it gives information on the removal process by the specific organism. Comparison of error functions values displayed in Table 2 was instrumental to deciding which model signified the rate limiting step. The minimum from 0.000159 of SEE, 1.9667 of NSD, -1.8728 of ARE and 0.00128 of RMSE was the focal value for the judgement.

As a rule, the model with the minimum error function values gives the best fit and indicate the rate limiting step of the process. In this instant removal case of As by Proteus mirabilis, pseudo first order model indicated by the ARE with minimum value of -1.8728 gave the best fit, and showed that the removal mechanism was reaction controlled. 
Table 2: Summary of Computed Error Functions for Arsenic Removal by Proteus Mirabilis

\begin{tabular}{|c|c|l|l|l|l|l|}
\hline Micro Organism & $\begin{array}{c}\text { Error } \\
\text { Function }\end{array}$ & $\begin{array}{c}\text { First Order } \\
\text { Kinetics }\end{array}$ & $\begin{array}{c}\text { Second Order } \\
\text { Kinetics }\end{array}$ & \multicolumn{1}{|c|}{ Elovich } & $\begin{array}{c}\text { Intraparticle } \\
\text { Diffusion }\end{array}$ & $\begin{array}{c}\text { Best Model } \\
\text { Selected }\end{array}$ \\
\hline \multirow{3}{*}{ Proteus mirabilis } & SEE & 0.0754 & 0.000159 & 0.000342 & 0.000242 & $\begin{array}{l}\text { Pseudo Second } \\
\text { Order }\end{array}$ \\
\cline { 2 - 7 } & NSD & 6.9233 & 1.9667 & 3.3621 & 2.2240 & $\begin{array}{l}\text { Pseudo Second } \\
\text { Order }\end{array}$ \\
\cline { 2 - 7 } & ARE & -1.8728 & 0.5456 & 0.9082 & 0.5937 & Pseudo First Order \\
\cline { 2 - 7 } & RMSE & 0.3868 & 0.00128 & 0.00208 & 0.00135 & $\begin{array}{l}\text { Pseudo Second } \\
\text { Order }\end{array}$ \\
\hline
\end{tabular}

Bacillus subtilis exerted removal influence on the metal ion, and the removal mechanism was chemisorption influenced. The three models for chemical process of removal were highlighted by the error functions utilized. SEE highlighted the simple Elovich model, NSD highlighted Pseudo second order model, RMSE highlighted the pseudo second order model, while ARE highlighted the pseudo first order model for removal. The information on Table 3 showed the values of these functions as 0.000110 for SEE, 1.1658 for NSD, -2.1208 for ARE, and 0.000363 for RMSE. The rate limiting step for this removal as indicated by the model with the minimum error function value is chemisorption which emanated from the pseudo first order model. And the removal mechanism was judged to be reaction controlled.

Table 3: Summary of Computed Error Functions for Arsenic Removal by Bacillus Subtilis

\begin{tabular}{|c|c|l|l|l|l|l|}
\hline Micro Organism & $\begin{array}{c}\text { Error } \\
\text { Function }\end{array}$ & $\begin{array}{c}\text { First Order } \\
\text { Kinetics }\end{array}$ & $\begin{array}{c}\text { Second Order } \\
\text { Kinetics }\end{array}$ & \multicolumn{1}{|c|}{ Elovich } & \multicolumn{1}{|c|}{$\begin{array}{c}\text { Intraparticle } \\
\text { Diffusion }\end{array}$} & $\begin{array}{c}\text { Best Model } \\
\text { Selected }\end{array}$ \\
\hline \multirow{3}{*}{ Bacillus substilis } & SEE & 0.0974 & 2.3908 & 0.000110 & 6.4267 & Elovich \\
\cline { 2 - 7 } & NSD & 7.6656 & 1.1658 & 2.6620 & 1.4833 & $\begin{array}{l}\text { Pseudo Second } \\
\text { Order }\end{array}$ \\
\cline { 2 - 7 } & ARE & -2.1208 & 0.3401 & 0.7312 & 0.4040 & Pseudo First Order \\
\cline { 2 - 7 } & RMSE & 0.5441 & 0.000363 & 0.000748 & 0.000409 & $\begin{array}{l}\text { Pseudo Second } \\
\text { Order }\end{array}$ \\
\hline
\end{tabular}

\subsection{Conclusion}

Kinetics of arsenic removal by Proteus mirabilis and Bacillus subtilis were studied using the nonlinear error functions approach. Four models namely pseudo first order, pseudo second order, simple Elovich, and intraparticle diffusion models were evaluated with SEE, NSD, RMSE and the ARE.

Data from removal by both organisms were best fitted with pseudo first order model indicated by the ARE of minimum value of -1.8728 for Proteus mirabilis, and -2.1208 for Bacillus subtilis. These showed that the removal mechanism was reaction controlled as chemisorption was the rate limiting step.

\section{References}

Aktan, Y., Tan, S. and Icgen, B., (2013). Characterization of lead-resistant river isolate Enterococcus faecalis and assessment of its multiple metal and antibiotic resistance. Environ. Monit. Assess., 185, pp. 5285-5293.

Athar, M. and Vohora, S.B., (2006). Heavy metals and environmental. New Age International (P) Limited Publishers, 4835/24, Ansari Road, Daryaganji, New Delhi-110002.

Atikpo, E. and Michael, A., (2018). Performance evaluation of six microorganisms ultilized for the treatment of lead contaminated agricultural soil. J. Appl. Sci. Environ. Manage., 22 (7), pp. 11051109.

Atikpo, E., (2016). Spatial distribution and attenuation of heavy metals pollution in amaonye ishiagu forest soils. PhD thesis submitted to the Department of Civil Engineering, University of Benin, Benin City, Nigeria. 
Badmus, M.A.O., Audu, T.O.K. and Anyata, B.U., (2007). Removal of lead ion from industrial wastewaters by activated carbon prepared from Periwinkle shells (Typanotonusfuscatus). Turk. J. Envi. Engin. Sci., 31, pp. 251-263.

Bailey, K.A., Smith, A.H., Tokar, E.J., Graziano, J.H., Kim, K.W. et al., (2016). Mechanisms underlying latent disease risk associated with early life arsenic exposure: current research trends and scientific gaps. Environ. Healt. Perspect., 124 (2), pp. 170-175.

Baron, E.J., Peterson, L.R. and Finegold, S.M., (1994). Bailey and scotts diagnostic microbiology. $9^{\text {th }}$ Edition. Mosby, Baltimore.

Chessebrough, M., (2000). District laboratory practice in tropical countries. Part 2, Cambridge low price edition, Cambridge University Press, London.

Chen, H. and Wang, A., (2007). Kinetic and isothermal studies of lead ion adsorption onto palygorskite clay. J. Collo. Interf. Sci., 307, pp. 309-316.

Chien, S.H. and Clayton, W.R., (1980). Application of Elovich equation to the kinetics of phosphate release and sorption on soil. J. Soil Sci., 44, pp. 265-268.

Cowan, S.T., (1993). Cowan and Steels Manual for the identification of medical bacteria. Cambridge University Press, London.

Cowan, S.T. and Steel, R., (1990). Manual for the identification of medical bacteria. Cambridge University Press, London.

Girma, G., (2015). Microbial bioremediation of some heavy metals in soils: an updated review. Indian J. Sci. Res., 6(1), pp. 147-161.

Ho, Y. S., (2006). Second-order-kinetic model for the sorption of cadmium onto tree fern: a comparison of linear and non-linear methods. Water Research, 40, pp. $119-125$.

Ho, Y.S., JohnWase, D.A. and Forster, C.F., (2000). Study of the sorption of dvalent metal ions onto peat. Adsorpti. Sci. Techno., 18, pp. 639-650.

Holt, J.C., (1994). The shorter bergeys manual of determinative bacteriology. Eight edition, Williams and Willkins Company, Baltimore.

Kulshreshtha1, A., Agrawal, R., Barar, M. and Saxena, S., (2014). A review on bioremediation of heavy metals in contaminated water. J. Environ. Sci. Toxicol. Foo. Techno., 8(7), pp. 44-50.

Kumar, K. V. and Porkodi, K., (2007). Mass transfer, kinetics and equilibrium studies for the biosorption of Methylene Blue using Paspalum notatum, J. Hazardo. Mate., 146, pp. 214-226.

Lima, E.C., Royer, B., Vaghetti, J.C.P., Brasil, J.L., Simon, N.M. et al., (2007). Adsorption of Cu(II) on Araucaria Angustifoliawastes: Determination of the Optimal Conditions by Statistic Design of Experiments. J. Hazar. Mate., 140, pp. 211-220.

Mckay, G. and Poots, V.J. (1980). Kinetics and diffussion processes in colour removal from effluent using wood as an adsorbent. J. Chem. Techno. Biotechno., 30, pp. 279-292.

Naujokas, M.F., Anderson, B., Ahsan, H., Aposhian, H.V., Graziano, J.H. et al., (2013). The broad scope of health effects from chronic arsenic exposure: update on a worldwide public health problem. Environ. Health. Perspect., 121(3), pp. 295-302.

Passos, C.G., Lima, E.C., Arenas, L.T., Simon, N.M., Da Cunha, B.M. et al., (2008). Use of 7-amine4-azahepthylsilica and 10-amine-4-azadecylsilica xerogels as adsorbent for $\mathrm{Pb}^{2+}$ kinetic and equilibrium study. Colloids Surfaces, 316, pp. 297-306. 
Smith, A.H., Marshall, G., Yuan, Y., Ferreccio, C., Liaw, J. et al., (2006). Increased mortality from lung cancer and bronchiectasis in young adults after exposure to arsenic in utero and in early childhood. Environ. Healt. Perspect., 114(8), pp. 1293-1296.

Steinmaus, C., Ferreccio, C., Acevedo, J., Yuan, Y., Liaw, J. et al., (2014). Increased lung and bladder cancer incidence in adults after in utero and early-life arsenic exposure. Canc. Epidemiol. Biomar. Prev., 23(8), pp. 1529-1538.

USEPA, (1996), Report: recent developments for in situ treatment of metals contaminated soils, U.S. Environmental Protection Agency, office of solid waste and emergency response.

Wuana, R. A. and Okieimen, F. E., (2011). Heavy metals in contaminated soils: a review of sources, chemistry, risks and best available strategies for remediation, international scholarly research network (ISRN), Ecology Volume, 2011, Article ID 402647, 20 pages. doi:10.5402/2011/402647. 